\title{
A VIOLÊNCIA SEXUAL COMO UMA FERRAMENTA DE GENOCÍDIO ${ }^{i}$
}

\author{
ANDREA SMITH ${ }^{\mathrm{ii}}$ \\ CHEROKEE
}

[O estupro] é nada mais nada menos que 0 processo consciente de intimidação através do qual o homem mantém a mulher em situação de medo ${ }^{1}$.

\section{O estupro como "nada mais nada menos" que uma ferramenta de controle patriarcal é o que fundamenta a filosofia do movimento antiviolência dominado pelas mulheres brancas. Tal filosofia foi criticada por mulheres de coriii, incluindo a pesquisadora teórica sobre questões}

\footnotetext{
${ }^{\mathrm{i}}$ Tradução de Bruna Zoch do primeiro capítulo de: SMITH, Andrea. Conquest: Sexual Violence and American Indian Genocide. Foreword by Winona LaDuke. Cambridge, MA: South End Press, 2005.

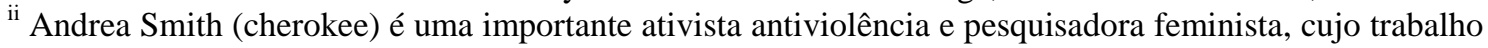
tem destacado as questões da violência contra as mulheres de cor e suas comunidades, especialmente contra as mulheres indígenas. Smith é cofundadora das seguintes organizações antiviolência, onde atua como ativista e pesquisadora nos comitês de planejamento nacional: "INCITE! Women of Color Against Violence", "the Boarding School Healing Project", e o "Women of All Red Nations". A organização "INCITE!" é um movimento de base que, através da ação direta e do diálogo crítico, busca acabar com a violência contra as mulheres de cor e suas comunidades. A segunda organização aborda o legado dos internatos, para onde milhares de crianças indígenas foram enviadas compulsoriamente. O legado de abusos, inclusive sexuais, é imenso, e o processo de cura passa pela denúncia e documentação dos casos para, enfim, exigir justiça. O terceiro grupo, também conhecido como WARN, foi fundado na década de 70, paralelamente ao AIM (American Indian Movement), para tratar de questões relacionadas com a violência contra a mulher, o fim do esteriótipo (como o uso de mascotes indígenas nos esportes), o cumprimento dos tratados, educação, saúde e assistência médica, meio ambiente, em especial os efeitos colaterais da extração de urânio em terras indígenas e a esterelização forçada de mulheres indígenas. Em reconhecimento ao seu trabalho, inclusive junto às Nações Unidas e a Anistia Internacional, Smith foi nomeada para o Nobel da Paz em 2005. O livro Conquest: Sexual Violence and American Indian Genocide, cujo primeiro capítulo estamos apresentando aqui, recebeu o prêmio Gustavus Myers Outstanding Book Award em 2005.

iii Women of color em inglês. A expressão of color na cultura norte-americana faz referência a todas as
}

Espaço Ameríndio, Porto Alegre, v. 8, n. 1, p. 195-230, jan./jun. 2014. 
raciais Kimberle Crenshaw, por sua falta de atenção ao racismo e a outras formas de opressão. Crenshaw analisa como conceitos de raça gerados por uma visão predominantemente masculina e conceitos de gênero criados por uma visão predominantemente branca impedem a compreensão clara da violência contra mulheres de cor. É inadequado, insiste ela, investigar a opressão contra a mulher de cor analisando a opressão de raça e gênero de maneira separada para então unir as duas análises, já que a concomitância entre racismo e sexismo modifica a dinâmica da análise. Ao invés disso, Crenshaw defende a substituição da abordagem de adição por uma de intersecção.

O problema não é que somente os dois discursos não abrangem a questão das mulheres de cor por não reconhecerem a questão "adicional" do patriarcalismo ou do racismo, mas que os dois discursos são frequentemente inadequados até para as tarefas distintas de articular toda a dimensão do racismo e do sexismo ${ }^{2}$.

Apesar da sua abordagem interseccional, Crenshaw desaponta na descrição de como a política de intersecção pode modificar fundamentalmente a maneira como se analisa a violência doméstica/sexual. Se a violência sexual não é só uma ferramenta do patriarcado mas também uma ferramenta do colonialismo e do racismo, então toda a comunidade de cor é vítima da violência sexual. Como argumenta Neferti Tadiar: as relações coloniais por si só são gendradas e sexualizadas.

As relações econômicas e políticas são configuradas de forma libidinal, ou seja, são dominadas e realizadas em termos de sexualidade. Essa fantasia global e regional não é, entretanto, somente metafórica, é real na medida em que abrangem um sistema de práticas políticas e econômicas já existente entre essas nações ${ }^{3}$.

Dentro desse contexto, de acordo com Tadiar: "a pergunta em questão é, quem está se dando bem aqui? Quem está se dando mal e por culpa de quem?"4. Dessa forma, tanto homens quanto mulheres indígenas têm sido submetidos ao domínio do terror sexual. A violência 
sexual não afeta homens e mulheres indígenas da mesma forma. Quando uma mulher indígena sofre abuso, isso é um ataque a sua identidade como mulher e a sua identidade como indígena. As questões de opressão por colonização, raça ou gênero não podem ser vistas separadamente. Tal fato explica porque durante minha experiência como conselheira de vítimas de abuso sexual sempre chegava um ponto em que a sobrevivente indígena dizia: "Não quero mais ser índia". Como vou mostrar neste capítulo, as mulheres de cor não só se deparam com um maior número de barreiras quando sofrem violência (e.g. menor atenção da mídia, barreiras de língua, falta de apoio no sistema legal) como suas experiências são qualitativamente desiguais das das mulheres brancas.

A análise de Ann Stoler sobre racismo lança luz sobre essa relação entre violência sexual e colonialismo. Ela argumenta que o racismo, longe de ser uma reação contra uma crise em que os chamados sujeitos de outras raças servem de bode expiatório para problemas sociais, é, na verdade, uma parte permanente do tecido da sociedade. "O racismo não é um efeito mas uma tática na fissura interna da sociedade entre posições binárias, uma maneira de criar inimigos internos "biologizados" contra os quais a sociedade precisa se defender"5. Ela observa que, no Estado moderno, é a constante purificação e eliminação de inimigos raciais dentro do Estado que garantem o crescimento do corpo nacional. "O racismo não emerge somente em épocas de crise, em limpezas esporádicas. É um elemento interno do Estado biopolítico, tecido na trama do corpo social, tramado no seu próprio tecido"6.

Do mesmo modo, Kate Shanley percebe que povos indígenas são uma "ausência presente" permanente no imaginário colonial estadunidense, uma "ausência" que reforça, cada vez mais, a convicção de que os povos indígenas estão realmente desaparecendo, e que a conquista das terras indígenas é justificada. Ella Shohat e Robert Stam descrevem essa ausência como:

um mecanismo repressivo ambivalente [que] dissipa a ansiedade em relação aos índios, cuja própria presença é um lembrete da precária fundação inicial do próprio Estado nação... Num paradoxo temporal, os índios vivos eram levados a fingir-se de mortos, por assim dizer, a fim de desempenhar o seu papel na narrativa

Espaço Ameríndio, Porto Alegre, v. 8, n. 1, p. 195-230, jan./jun. 2014. 
do destino manifesto que, no fim das contas, era de desaparecer ${ }^{7}$.

Essa "ausência" se realiza através da transformação metafórica dos corpos indígenas em uma poluição, de que o corpo colonial deve constantemente se purificar. Por exemplo, em 1860, os californianos brancos descrevem os indígenas como "a porção de seres humanos mais sujos da Terra"8. Eles usavam "trapos imundos, nos seus corpos não lavados, com cabelo despenteado e repleto de vermes"9. O comercial da Procter \& Gamble [P\&G] de 1885 para o sabão Ivory também ilustra essa equiparação do corpo dos índios com sujeira:

Nós já fomos facciosos, violentos e selvagens
na arte da paz irreconciliáveis
Nossos cobertores cheios de banha e manchas
De carne de búfalo e sangue de colonizador
Através da poeira do verão e o prazer do calor.
Por luas e mais luas nos abstivemos de lavar,
Mas o Ivory Soap veio como que num clarão
De luz por entre nosso caminho de escuridão
E agora nos tornamos civis, dóceis e bons
E cumprimos as leis, como todas as pessoas
Usamos linho, algodão e renda
Como os companheiros de caras pálidas
E levo comigo, onde quer que eu vá
Essa barra de Ivory Soap para mostrar
O que tornou minha squaw ${ }^{i v}$ e eu civilizados
E nos tornou limpos e claros ${ }^{10}$.

No imaginário colonial, os corpos dos índios também estavam imanentemente poluídos com o pecado sexual. Os teóricos Albert Cave, Robert Warrior, H.C. Porter, entre outros, demonstraram que os colonizadores cristãos frequentemente associavam os povos indígenas com a figura bíblica dos cananeus, ambos merecedores da destruição em massa'1. O que torna os cananeus supostamente merecedores de destruição, na narrativa bíblica, e os povos indígenas supostamente merecedores de destruição, aos olhos dos colonizadores, é que os dois grupos personificam o pecado sexual. Na bíblia, os cananeus cometem atos de perversão sexual em Sodoma (Gên. 19:1-29), são descendentes da repugnante relação entre Ló e suas filhas (Gên. 19:30-38), são descendentes do libertino e perverso Cam (Gên. 9:22-27), e se

\footnotetext{
${ }^{\text {iv }}$ Squaw é um termo pejorativo do inglês para se referir às índias [nota da tradução].
} 
prostituem em prol de seus deuses (Gên. 28:21-22, Deut. 28:18, Reis I 14:24, Reis II 23:7, Oséias 4:13, Amós 2:7).

Do mesmo modo, aos olhos do colonizador, os povos indígenas eram marcados por sua perversidade sexual. Alexander Whitaker, pastor da Virgínia, escreveu em 1613: "Eles vivem com os corpos expostos, como se a vergonha de seus pecados não merecesse ser coberta. Seus nomes são tão expostos como seus corpos: consideram uma virtude mentir, enganar e roubar, como seu mestre, o demônio, Ihes ensinou"12. Além disso, de acordo com Bernardino de Minaya, um clérigo dominicano: "Seus matrimônios não são um sacramento mas um sacrilégio. São idólatras, libidinosos, e cometem sodomia. Sua ânsia principal é comer, beber, adorar deuses pagãos, e cometer obscenidades bestiais" 13 .

Já que os corpos dos índios são "sujos", são considerados sexualmente violáveis e "estupráveis", e o estupro de corpos considerados inerentemente impuros ou sujos simplesmente não conta. Por exemplo, quase nunca se acredita no relato de prostitutas quando dizem terem sido estupradas, porque a sociedade dominante considera o corpo de profissionais do sexo como não sendo merecedor de integridade e admissível de violação a qualquer momento. Da mesma maneira, a história de mutilação dos corpos dos índios, tanto vivos quanto mortos, deixa claro que os indígenas não são merecedores de integridade física.

Vi o cadáver de White Antilope com seus genitais cortados, e ouvi um soldado dizendo que faria uma bolsa para tabaco deles ${ }^{14}$.

À noite, o Dr. Rufus Choate e o Tenente Wentz C. Miller... subiram a ravina, decapitaram o mortos dos Qua-ha-das e colocaram suas cabeças em sacos de juta, e as trouxeram para serem fervidas em prol de pesquisas científicas ${ }^{15}$.

Cada um dos guerreiros era derrubado e escalpelado por voluntários selvagens, que sacavam suas facas e faziam dois talhos paralelos de fora a fora nas costas, e retiravam a pele ainda palpitante para fazer delas tiras de afiar navalha ${ }^{16}$.

Dr. Tuner, de Lexington, Iowa, visitou esta sepultura solitária [de Black Hawk] e roubou o seu ocupante... enviou o corpo a Alton, Illinois, onde o esqueleto foi novamente ligado com arame. [O corpo foi enviado de 
volta] mas permaneceu aqui por pouco tempo antes de novos vândalos o tomarem levando-o para Burlington, para o Iowa Geographical and Historical Society (Departamento Histórico-geográfico de Iowa), onde foi consumido pelo fogo em $1855^{17}$.

Um deles, mais habilidoso que os outros, começou a tirar a pele do corpo do chefe [o Tecumseh]; continuou a cortar a pele em tiras estreitas...e preparou um estoque de tiras de afiar navalha para os mais "ferozes" de seus irmãos ${ }^{18}$.

Andrew Jackson... acompanhou de perto a mutilação de cerca de 800 corpos de índios Creek - os corpos de homens, mulheres e crianças que ele e seus homens massacraram - tirando e preservando os narizes para contar e preservar um registro dos mortos, tirando finas tiras de carne dos seus corpos, para curtir e fazer rédeas ${ }^{19}$.

Algumas noites depois, alguns soldados cavaram para tirar o corpo do Mangus novamente, deceparam sua cabeça e ferveram-na durante a noite, preparando o crânio para ser levado ao museu de Nova Iorque ${ }^{20}$.

Em 1990, o governador de Illinois, Jim Thompson, reproduziu esses sentimentos ao recusar-se a fechar uma sepultura-monte indígena aberta na cidade de Dixon. O Estado de Illinois construiu um museu ao redor desse monte, para expor restos mortais indígenas ao público. Thompson alegou que ele era tão índio quanto os índios de hoje em dia e que, por consequência, tinha tanto direito quanto eles de determinar o destino a ser dado aos restos mortais indígenas ${ }^{21}$. Os restos eram "dele". Do mesmo modo, a impressa de Chicago, tentou questionar a identidade da nação indígena que estava protestando contra a decisão do governador, afirmando que eles eram só "parte" indígenas, ou estavam só reivindicando serem índios ${ }^{22}$. De fato, o governo de Illinois estava passando a mensagem aos índios de que estar constantemente expostos para os consumidores brancos, tanto em vida quanto depois de mortos, é aceitável. Além disso, a própria identidade indígena está sob o controle do colonizador, e sujeita a questionamento ou erradicação a qualquer momento.

Em 1992, o ministro de finanças de Ontário, Jim Flaherty, propôs que o governo canadense poderia aumentar a dotação orçamentária dos serviços de saúde para "pessoas de verdade em cidades de verdade", diminuindo a burocracia que favorecia somente os indígenas ${ }^{23}$. 0 fato 
de que os índios não são vistos, no discurso colonial dominante, como pessoas "de verdade" indica o sucesso da violência sexual, além do de outras forças racistas e coloniais, na destruição da percepção da humanidade dos povos indígenas. Conforme argumenta Aime Cesaire, colonização $=$ coisificação $^{24}$. Stoler explica esse processo de colonização racializada:

Quanto mais os degenerados e anormais [nesse caso, os povos indígenas] forem eliminados; a vida daqueles que falam será mais forte, vigorosa e melhor. Os inimigos não são os adversários políticos, mas aqueles reconhecidos como ameaças internas e externas à população. O racismo é a condição que torna plausível levar [certas pessoas] a morte numa sociedade de normatizações ${ }^{25}$.

O projeto de prática de violência sexual nas colônias estabelece a ideologia de que os corpos indígenas são naturalmente violáveis - e, portanto, as terras indígenas também são naturalmente violáveis.

Em consequência dessa colonização e do abuso de seus corpos, os índios aprenderam a internalizar o ódio de si próprios, porque a imagem corporal é totalmente relacionada à autoestima. Quando o corpo de uma pessoa não é respeitado, ela começa a se odiar ${ }^{26}$. Anne, uma indígena que estudou em um internato, reflete sobre esse processo:

É melhor você não se tocar... Se eu olhasse pra alguém...luxúria, sexo, e eu ficava com medo dessas sensações sexuais. Eu não sabia como lidar com elas... O que me deixava mais confusa era que, se relação sexual era pecado, por que as pessoas nasciam?... Demorei muito tempo para superar o fato de que... pequei: tive um filho ${ }^{27}$.

Como suas palavras demonstram, quando os corpos dos índios são definidos como inerentemente pecaminosos e sujos, o simples fato de ser índio se torna um pecado. Os indígenas internalizam o projeto genocida através da autodestruição. Como conselheira em casos de estupro, não me surpreendia que os índios que sobreviveram a um abuso sexual com frequência dissessem que não queriam mais ser índios. A experiência individual de violação sexual dos povos indígenas 
ecoa 500 anos de colonização sexual, em que os corpos dos povos indígenas foram considerados inerentemente impuros. Chrystos, uma poeta menominee, escreve, com esta voz, em seu poema "Old Indian Granny" [Vó Indígena]:

$$
\begin{aligned}
& \text { Você me contou sobre todas as índias que já } \\
& \text { aconselhou } \\
& \text { Que disseram não quererem mais ser índias } \\
& \text { Porque um homem branco ou um índio as estuprou } \\
& \text { Ou matou seu irmão } \\
& \text { Ou tentou atropelá-la na rua } \\
& \text { Ou as insultou ou fez tudo isso } \\
& \text { O pão nosso de ódio de cada dia } \\
& \text { Ás vezes nem eu quero ser índia } \\
& \text { Mas nunca disse isso antes em alto e bom som } \\
& \text { Além da fome } \\
& \text { Da falta de onde dormir ou de onde dançar } \\
& \text { De não ter um emprego ou um lar decente para } \\
& \text { oferecer a Vó } \\
& \text { É saber, com cada sopro invisível de vida, } \\
& \text { Que se você não fizer algo bonito } \\
& \text { Para que eles possam por na parede ou a redor de seus } \\
& \text { pescoços } \\
& \text { Você poderia estar morta }{ }^{28} \text {. }
\end{aligned}
$$

O projeto de assistência técnica da Mending the Sacred Hoop [Remendando a roda de cura] de Duluth, Minnesota, relata que a primeira barreira que os defensores da antiviolência enfrentam ao abordar assuntos de violência em territórios indígenas é que os próprio membros da comunidade dizem que a violência sexual é "tradicional". Esse fenômeno mostra o quanto as nossas comunidades internalizaram o ódio de si mesmos. Frantz Fanon argumenta: "No contexto colonial, como já apontamos anteriormente, os indígenas lutam entre si, usam uns aos outros como uma tela de proteção e cada um esconde do seu vizinho o inimigo nacional"29. Desse modo, como Michael Taussig observa: os povos indígenas são retratados pela cultura dominante como naturalmente violentos, autodestrutivos e disfuncionais ${ }^{30}$. Por exemplo, o cidadão Mike Whelan fez a seguinte afirmação, numa audiência de zoneamento em 1990, clamando pelo indeferimento de uma permissão concedida para um abrigo para mulheres indígenas agredidas em Lake Andes, Dakota do Sul.

Espaço Ameríndio, Porto Alegre, v. 8, n. 1, p. 195-230, jan./jun. 2014. 
A cultura indígena como eu a vejo, está tão miscigenada atualmente, que é uma mescla de dependência do Governo Federal e de uma sociedade primitiva que foge aos padrões da civilização e do pensamento ocidental. A Cultura Indígena, como a conhecemos hoje, não como a de antigamente, é uma cultura sem esperança, sem deus, sem emprego, e sem lei... O alcoolismo, a doença social, o abuso infantil e a pobreza são as características marcantes dessa intitulada cultura, que você procura promover, e eu the diria que os bravos da dança dos fantasmas ${ }^{\vee}$ iriam se envergonhar com o que agora se vê como sendo sua cultura... Para mim, o que você chama de modo de vida indígena significa marcas de queimadura de cigarros nas mãos de crianças, se certificar das travas do carro, manter uma arma carregada ao lado da minha porta, além de sucatas de carros e latas de cerveja no pátio da frente... Não é uma questão de raça, é uma questão de manter a nossa comunidade e a nossa vizinhança longe desse mal que você e suas ideias promovem ${ }^{31}$.

Do mesmo modo, num caso recente entre os povos aborígenes da Austrália, um juiz julgou que o estupro de uma menina de quinze anos por um aborígene de cinquenta anos não era um crime sério, mas sim um exemplo da cultura tradicional. Considerou que a menina "sabia o que era esperado dela" e "não precisava de proteção" quando foi estuprada pelo homem que já havia sido condenado por assassinar a sua ex-esposa. Um "especialista" em antropologia testemunhou no caso, dizendo que o estupro era "tradicional" e "moralmente correto"32. De acordo com Judy Atkinson, uma professora universitária aborígene, sobreviventes relataram que vários funcionários do poder judicial ignoram relatos de violência por considerarem que tal violência é "um comportamento cultural". "Vivemos numa zona de guerra nas comunidades aborígenes", diz Atkinson. "Vários comportamentos emergem nesses contexto", diz ela. "E mesmo assim os tribunais estão validando esse comportamento" 33 .

Taussig comenta sobre a ironia dessa lógica: "Os homens não são conquistados pela invasão, mas por eles mesmos. É um sentimento estranho, não é mesmo?, quando encaramos tanta evidência brutal de

\footnotetext{
" Ghost Dance, no original. A tradução mais correta do significado original seria "Dança dos Espíritos". No entanto, a língua inglesa adotou, ao longo de sua história, a tradução equivocada reproduzida aqui [nota da tradução].
}

Espaço Ameríndio, Porto Alegre, v. 8, n. 1, p. 195-230, jan./jun. 2014. 
invasão"34. Mas, como observa Fanon, esse comportamento destrutivo não é "uma consequência da organização do sistema nervoso ou de uma originalidade do caráter, mas um produto direto do sistema colonial"35.

A descrição de Tadiar das relações coloniais como uma manifestação do "modo predominante das relações heterossexuais" é útil porque ressalta como os colonizadores dos Estados Unidos veem a subjugação das mulheres das nações indígenas como crucial para o sucesso da colonização econômica, cultural e política ${ }^{36}$. Stoler observa que os discursos imperiais sobre a sexualidade "colocam a mulher branca como portadora de uma ordem imperial mais racista"37. Por extensão, as mulheres indígenas são portadoras de uma ordem antiimperial e representam uma grande ameaça à cultura dominante. $O$ controle simbólico e literal dos corpos das indígenas é muito importante na guerra contra os indígenas, como ilustram estes testemunhos:

Quando eu estava no navio capturei uma bela caribenha... concebi desejo para ter prazer... Peguei uma corda e a açoitei bem, de maneira que ela emitisse gritos tão inaudíveis que você não acreditaria nos seus ouvidos. Por fim, chegamos a um acordo de tal maneira que, posso the dizer que parecia que ela havia sido criada numa escola de meretrizes ${ }^{38}$.

Duas das mais belas squaws ${ }^{\text {vi }}$ estavam numa posição, que pela aparência de seus órgãos genitais e das feridas, não deixavam dúvida de que haviam sido primeiramente violentadas e, então, mortas a tiro. Quase todos os mortos foram mutilados ${ }^{39}$.

Uma mulher, com a gravidez já bastante avançada, invadiu a igreja, agarrando-se ao altar e clamando por misericórdia por ela e por seu filho ainda não nascido. Ela foi seguida e caiu atravessada por uma dúzia de lanças... A criança foi arrancada viva do corpo ainda palpitante de sua mãe, primeiro mergulhada em água benta para ser batizada e imediatamente arremessada de cabeça contra a parede ${ }^{40}$.

Os cristãos os atacaram com socos e pancadas... E então os cristãos passaram a agir com tanta audácia e descaramento que o líder mais poderoso da ilha teve de ver sua própria esposa estuprada por um líder cristão ${ }^{41}$. Ouvi um homem dizer que havia cortado fora as partes íntimas de uma mulher e depois exibido-as numa vara. Ouvi outro homem dizer que havia cortado os dedos de um índio fora para tirar os anéis dele. Também ouvi

\footnotetext{
${ }^{\text {vi }}$ Ver nota iv.
}

Espaço Ameríndio, Porto Alegre, v. 8, n. 1, p. 195-230, jan./jun. 2014. 
vários casos de homens que haviam cortado fora as partes íntimas de mulheres e estendido-as sobre suas selas, e alguns deles, em seus chapéus ${ }^{42}$.

A história da violência sexual e do genocídio contra as mulheres indígenas ilustra como a violência gendrada funciona, em geral, como uma ferramenta do racismo e do colonialismo entre as mulheres de cor. Por exemplo, as mulheres afro-americanas também eram vistas como naturalmente estupráveis. No entanto, enquanto os colonizadores faziam uso de violência sexual para eliminar as populações nativas, os proprietários de escravos utilizavam o estupro para reproduzir uma mão de obra explorável (os filhos de mulheres negras herdavam delas a sua condição de escravos). Como as mulheres negras eram vistas como propriedade de seus donos, o estupro perpetrado por esses homens não "contava". Como uma estadista sulista declarou no início do século vinte, não havia uma "menina de cor virtuosa" com mais de 14 anos43. Os testemunhos das narrativas de escravos e de outras fontes revelam o abuso sistemático das escravas pelos proprietários brancos de escravos.

Durante quatro meses, incluindo as últimas semanas de gravidez, o parto, e a recuperação... ele bateu nela com tacos, correntes de ferro e outras armas mortais inúmeras vezes; queimava-a; infligia-Ihe listras repetidas com o açoite, que literalmente deixava seu corpo todo escoriado; forçava-a a trabalhar em estações severas, sem estar devidamente agasalhada, dava-Ihe comida insuficiente, exigia trabalho além da suas forças e, descontroladamente, batia nela porque ela não conseguia atender a suas exigências. Essas atrocidades; além de outras, repugnantes demais, particularmente designadas, o prisioneiro, sem compaixão alguma no coração, praticou... até as últimas horas de existência da vítima.

[Relato de abuso e consequente assassinato de uma escrava perpetrado por um proprietário de escravos, da Carolina do Norte $]^{44}$.

[O meu senhor] era um homem bom, mas era muito mau com as mulheres. Casadas ou não, não tinha diferença para ele. Quem quer que ele desejasse entre as escravas, ele ia e a pegava ou a fazia encontrá-lo lá no mato. Eu sabia que ele ia até a cabana e fazia o marido da escrava esperar sentado do lado de fora, enquanto ele penetrava sua esposa... Ele não era pior que nenhum outro. Todos usavam suas escravas como bem queriam, e não havia ninguém que falasse alguma

Espaço Ameríndio, Porto Alegre, v. 8, n. 1, p. 195-230, jan./jun. 2014. 
coisa contra. Nem o escravo, nem a escrava podiam fazer nada. Se sujeitavam a isso mas se mantinham rezando a Deus.

[Depoimento de um escravo da Carolina do Sul] ${ }^{45}$.

"Algumas tropas", reclamou um branco ao seu comandante Rufus Saxton, "forçaram sua entrada nas casas dos negros e depois de expulsarem os homens (em uma delas, com baionetas) tentaram violentar as mulheres." Quando os homens protestaram e tentaram proteger "suas esposas e irmãs," "foram brutalmente golpeados e ameaçados de morte." "Os costumes das velhas plantations" lamentou Saxton, "parecem ter se restabelecido nos exércitos de ocupação."

[Relato das atividades dos soldados da União durante a Guerra Civil] $]^{46}$.

As mulheres imigrantes também passaram por uma longa história de exploração sexual nos Estados Unidos. Por exemplo, leis trabalhistas racistas forçaram milhares de imigrantes chinesas à prostituição. Para complementar sua renda escassa, famílias chinesas empobrecidas com frequência vendiam suas filhas para a prostituição. Outras mulheres foram atraídas aos EUA com a promessa de um casamento estável ou de um emprego, só para descobrirem que ficaram presas ao comércio sexual. Em 1860, quase um quarto dos chineses de São Francisco (todas mulheres) estavam trabalhando na prostituição47.

Karen Warren argumenta que a sociedade patriarcal é um sistema disfuncional que espelha a família nuclear disfuncional. Ou seja, o abuso intenso na família continua porque os membros da família aprendem a considerar isso "normal". Uma vítima de abuso passa a ver que o seu abuso não é "normal" quando ela entra em contato com famílias menos abusivas. Do mesmo modo, Warren argumenta, a sociedade patriarcal é um sistema disfuncional baseado na dominação e na violência. "Os sistemas disfuncionais normalmente se mantém através da negação sistemática, uma incapacidade ou inabilidade de enxergar a realidade de uma situação. Essa negação não precisa ser consciente, intencional ou maliciosa; ela só precisa ser generalizada para ser eficiente" 48 .

$\mathrm{Na}$ época das viagens de exploração de Colombo, a sociedade europeia era um sistema disfuncional, abalado por miséria generalizada, doenças, opressão religiosa, guerra, e violência institucionalizada. Por exemplo, durante a Inquisição, centenas de milhares de judeus foram massacrados, e suas propriedades confiscadas foram utilizadas para

Espaço Ameríndio, Porto Alegre, v. 8, n. 1, p. 195-230, jan./jun. 2014. 
financiar as viagens de Cristóvão Colombo. David Stannard relata:

A violência, claro, estava em todo lugar... Em Milão, em 1476, um homem foi dilacerado em pedaços por uma multidão enfurecida, e seus membros arrancados foram devorados por seus torturadores. Em Paris e em Lyon, os huguenotes foram mortos e desmembrados, e as várias partes dos seus corpos foram vendidas livremente nas ruas. Outras explosões de tortura bizarra, assassinato e canibalismo ritual não eram incomuns ${ }^{49}$.

Além disso, as sociedades europeias eram completamente misóginas. O patriarcado cristão que estruturava a sociedade europeia era intrinsecamente violento, como foi amplamente documentado ${ }^{50}$. Por exemplo, uma vez que não era permitido às inglesas expressarem suas opiniões políticas, uma mulher que se manifestou contra os impostos, em 1664, foi condenada a ter sua língua pregada a uma árvore próxima à estrada, com uma placa afixada às suas costas detalhando sua ofensa ${ }^{51}$. $O$ ódio às mulheres se manifestou mais amplamente na caça às bruxas. Em algumas cidades inglesas, cerca de um terço da população foi acusado de bruxaria52. As mulheres alvo de destruição eram aquelas que se mostravam mais independentes da autoridade patriarcal: mulheres solteiras, viúvas e curandeiras ${ }^{53}$.

A natureza mais pacífica e igualitária das sociedades indígenas não escapou da percepção dos colonizadores. No período "colonial", foi um escândalo nas colônias o fato de que uma quantidade considerável de brancos escolheu viver entre os índios, embora virtualmente nenhum indígena tenha escolhido, de forma voluntária, viver entre os colonos. De acordo com J. Hector St. John de Crevecoeur, o autor de Cartas de um fazendeiro americano, do século XVIII: "Milhares de europeus são indígenas, e nós não temos nenhum exemplo de um desses aborígenes sequer ter se tornado europeu por escolha própria"54. Os colonos também perceberam que raramente os indígenas cometiam violência sexual contra seus prisioneiros brancos, ao contrário dos colonos. 0 brigadeiro James Clinton, do Exército Continental, disse a seus soldados quando foram enviados para destruir a nação Iroquois, em 1779: "Bárbaros como são os selvagens, eles nunca tentam violar a castidade de nenhuma prisioneira" 55 . William Apess, um pequot do século XIX, 
indagou: "Onde, nos registros das barbáries indígenas, podemos encontrar uma mulher uma mulher violada?"56. Shohat e Stam argumentam que o propósito real por trás do terror colonial "não era forçar os indígenas a se tornarem europeus, mas impedir que os europeus se tornassem indígenas" 57 .

Em contraste com a forte natureza patriarcal das sociedades europeias antes da colonização, as sociedades indígenas, em sua maioria, não eram dominadas pelos homens. As mulheres atuavam como líderes espirituais, políticas e militares, e muitas sociedades eram matrilineares. Mesmo havendo uma divisão de tarefas entre homens e mulheres, ao trabalho da mulher e ao trabalho do homem era concedido o mesmo status 58. Como os homens e as mulheres vivam em harmonia, as sociedades indígenas eram, por consequência, muito menos autoritárias que suas correlatas europeias. Paul Lejeune, um padre jesuíta, observou no século dezessete:

[Os indígenas] imaginam que eles têm o direito de nascença de desfrutar a liberdade de um potro selvagem, não devendo tratar com honrarias a quem quer que seja, exceto quando eles quiserem... Toda a autoridade do seu cacique está na ponta da sua língua, pois ele tem poder até onde for sua eloquência; e, mesmo que ele se mate falando e discursando, ele não será obedecido se não agradar aos selvagens ${ }^{59}$.

Além disso, setenta porcento das tribos não guerreava, de maneira alguma60. E entre aqueles que se envolviam em guerra, a intenção geralmente não era de aniquilar o inimigo, mas sim de obter honra através da bravura. Era mais honroso chegar perto o suficiente do inimigo para tocá-lo, deixando-o vivo, do que matá-lo. Tom Holms escreve:

As guerras indígenas tradicionais tinham muito mais em comum com os esportes de contato euro-americanos, como o futebol, o boxe e o hockey, do que com as guerras travadas ao modo europeu. Isso, é claro, não quer dizer que ninguém morria... Eles morriam - assim como acontece nos esportes de contato modernos mas o objetivo do exercício não tinha, via de regra, o propósito letal ${ }^{61}$. 
É claro que, ao discutir tais tendências, convém não generalizar demais ou dar a impressão de que as comunidades indígenas eram utópicas antes da colonização. Certamente havia violência gendrada antes da colonização. Todavia, tanto os registros orais quanto escritos frequentemente mostram que ela é relativamente rara, assim como a severidade na punição para os perpetradores de violência,. Este relato de uma punição por agressão sexual entre os kiowa serve de ilustração:

\begin{abstract}
As kiowas causaram tanto constrangimento e zombaram tanto do criminoso que dizem que ele morreu logo. O homem era um estuprador recorrente a quem as mulheres finalmente ensinaram o erro dos seus atos; elas armaram uma emboscada e deixaram uma bela jovem como isca. Quando ele mordeu a isca, elas apareceram de repente e o dominaram. Enquanto as outras o seguravam imobilizado no chão, uma por vez levantava a saia e sentava em seu rosto. A experiência em si não era fatal, mas a perda de status decorrente do desprezo que ela gerava era. A possibilidade de uma punição drástica era, talvez, mais corretiva por seu efeito do que a ameaça da cadeira elétrica em sociedades mais sofisticadas ${ }^{62}$.
\end{abstract}

Havia uma prática similar entre os anishinabe:

Bater na esposa, como já vimos, não era nem aceito nem tolerado entre os anishinabe, mesmo depois da liberdade de viverem como ojibwe ter sido restringida. A agressão à esposa surgiu juntamente com a desintegração do modo de vida ojibwe e com o início do uso do álcool. O comportamento dos ojibwe sob a influência do álcool é frequentemente contrário aos valores anishinabe. É essencialmente contrário à autodisciplina que se fazia necessária para o desenvolvimento do caráter ojibwe.

Não há nenhuma filosofia entre as pessoas da sociedade de hoje relacionada com a doença social da agressão à esposa. Muitos esqueceram ou não receberam os ensinamentos das leis sociais que embasam a sociedade. $\mathrm{Na}$ antiga sociedade ojibwe, a própria sociedade era responsável pelo que acontecia dentro dela; o que não acontece hoje. Qual a evidência dessa afirmação? O ciclo nocivo, destrutivo, traumático de violência doméstica que está atingindo as Crianças Anishinabe da Nação.

Hoje, já perdemos muito da tradição, dos valores, do modo de vida, das leis, da língua, dos ensinamentos

Espaço Ameríndio, Porto Alegre, v. 8, n. 1, p. 195-230, jan./jun. 2014. 
dos velhos, do respeito, da humildade como povo anishinabe por causa da mentalidade europeia que aceitamos. Para os anishinabe sobreviverem como uma Nação, devemos voltar juntos as páginas do tempo. Devemos encarar a realidade, nos avaliarmos como um povo - o porquê de termos sido criados para viver em harmonia um com o outro como povo anishinabe e para viver em harmonia com a criação do Criador $^{63}$.

As mulheres europeias amiúde se surpreendiam ao descobrir que, mesmo durante a guerra, elas não eram abusadas por seus capturadores indígenas. Mary Rowlandson contou sobre sua experiência: "Estive entre Leões rugindo e Ursos Selvagens, que não temiam nem Deus nem o Homem, nem o Diabo... e mesmo assim nenhum deles intentou abuso contra a minha castidade, em palavra ou em atitude"64. Entre 1675 e 1763, cerca de quarenta porcento das mulheres raptadas por indígenas na Nova Inglaterra escolheram continuar com seus capturadores ${ }^{65}$. Em 1899, um editorial assinado pela Sra. Teall apareceu no Syracuse Herald-Journal, discutindo o status da mulher na sociedade iroquois:

Eles têm um costume que, mesmo nos dias atuais, o homem branco não está preparado para aceitar. As mulheres dos iroquois ocupavam posições públicas e eram influentes. Elas tinham um conselho próprio... que tinha a iniciativa nas discussões; os assuntos apresentados por elas eram levados ao conselho de chefes e dos velhos para resolução; e neste as mulheres tinham um orador próprio (normalmente uma oradora) para apresentar e falar por elas. Ocasionalmente há chefes mulheres... A esposa possuía toda a propriedade... A família era dela; os descendentes eram contados a partir da mãe ${ }^{66}$.

Em resposta ao seu editorial, um homem que assinou como "Estudante" respondeu:

As mulheres entre os iroquois, diz a Sra. Teall... tinham seu próprio conselho, além de oradoras e chefes. Por que ela não acrescenta as explicações a seguir de por que sedava tal distinção às mulheres, pois "na tortura de prisioneiros acreditava-se que as mulheres eram mais sutis e habilidosas que os homens" e os homens da inquisição eram superados por esses selvagens na

Espaço Ameríndio, Porto Alegre, v. 8, n. 1, p. 195-230, jan./jun. 2014. 
sutileza da crueldade praticada nas vítimas. Também é verdade que a sucessão era através da mulher, e não do homem, nas tribos iroquois, mas a explicação para isso é que, no geral, era difícil dizer quem era o pai da criança... Uma moça indígena nunca aprendia a ter vergonha. Os índios, a respeito de quem tanto se desperdiçou retórica, eram um bando de selvagens impiedosos que nunca teriam chegado perto de qualquer tipo de civilização se não tivessem sido encontrados por missionários e comerciantes... Sua gana era de destruir e devastar, de tostar suas vítimas e comê-las, de mentir e roubar, de viver na sujeira, homens, mulheres, crianças, cães e pulgas todos amontoados $^{67}$.

Portanto, a demonização da mulher indígena pode ser vista como uma estratégia do homem branco para manter o controle sobre a mulher branca. Essa demonização é exemplificada pelas narrativas de cativeiro que se tornaram um gênero popular nos Estados Unidos68. Essas narrativas eram supostamente narrativas em primeira pessoa de mulheres brancas que haviam sido abduzidas pelos "selvagens" e forçadas a submeter-se a selvagerias incontáveis. Suas histórias, no entanto, eram normalmente escritas por homens brancos que tinham sua própria pauta ideológica. Em 1823, por exemplo, James Seaver de Nova lorque entrevistou Mary Jemison, que havia sido raptada pelos Seneca. Jemison escolheu continuar vivendo entre eles quando lhe foi oferecida a liberdade, porém Seaver está convencido de que ela está protegendo o povo indígena ao não descrever toda a sua selvageria. "Os vícios dos indígenas, ela parecia não estar disposta a agravar e parecia ter orgulho de exaltar as suas virtudes. Uma espécie de orgulho de família a induziu a negar o que quer fosse manchar o caráter de seus descendentes e talvez a induziu a reprimir muitas das coisas que teriam sido interessantes"69. Consequentemente, ele acrescentou a sua narrativa material oriundo "de fontes seguras" e do primo de Jemison, George ${ }^{70}$. Seaver, no entanto, atribuiu tais acréscimos à voz dela nessa narrativa supostamente em primeira pessoa.

Nessas narrativas, podemos encontrar o que Carol Adams define como o "referente ausente". Adams fornece um exemplo quando observa como o termo "mulheres agredidas" torna as mulheres vítimas inerentes de agressão. O agressor torna-se invisível e, portanto, é o 
referente ausente ${ }^{71}$. Outro exemplo do referente ausente pode ser encontrado no símbolo cristão da crucificação, em que Jesus é representado como aquele cuja natureza e propósito inerente é ser crucificado. Os indivíduos que o colocaram na cruz, nunca retratados nas representações do crucifixo, são apagados como agressores e se tornam o referente ausente.

Andrea Dworkin argumenta que, num sistema patriarcal, "o homem se distingue da mulher pelo seu comprometimento em causar a violência ao invés de ser vitimizado por ela. $\mathrm{Na}$ adoração à violência - da crucificação de Cristo ao retrato cinematográfico do General Patton - o homem busca adorar a si mesmo"72. June Namias argumenta que o intuito dessas representações é induzir as mulheres brancas a crer que elas precisam do homem branco para protegê-las dos selvagens ${ }^{73}$. Jane Caputi também sugere que, nas representações de assassinatos de mulheres, o assassino atua como alter ego do leitor ou do espectador masculino. "Essa convenção permite que esse espectador se gratifique imaginando-se, simultaneamente, em dois papeis masculinos que se reforçam mutuamente. Ele é... tanto o protetor quanto a ameaça"74. De acordo com Jane McCrea, o homem branco simbolicamente mata a mulher branca através dos índios, que refletem seus desejos, e adiantase em resgatá-la. O homem branco está ausente quando a violência ocorre. No entanto, é ele quem cria a imagem em que o homem branco é o referente ausente. Ele glorifica sua habilidade de brutalizar a mulher branca através do selvagem indígena enquanto nega sua culpabilidade.

Entretanto, as mulheres indígenas estão completamente ausentes dessa representação, e, consequentemente, a sua real brutalização sexual nas mãos do homem branco deixa de ser percebida. O homem branco literalmente a brutaliza, embora simbolicamente brutalize a mulher branca através da sua prática representacional. Os indígenas servem de bode expiatório para as ações dos homens brancos, de forma que as mulheres os enxergarão como o inimigo, enquanto os homens brancos se mantém isentos de responsabilidade.

Paula Gunn Allen argumenta que os colonizadores perceberam que, para subjulgar as nações indígenas, eles teriam de subjulgar as mulheres dessas nações. Os povos indígenas precisavam aprender 0 valor da hierarquia, o papel do abuso físico na manutenção da 
hierarquia e a importância de manter as mulheres submissas aos seus homens. Precisavam convencer "os homens e as mulheres de que o lugar adequado para a mulher era sob a autoridade do marido e para o homem, sob a autoridade do padre"75. Ela segue seu argumento dizendo que:

Era vantajoso para o homem branco enganar a mulher branca, e a si mesmo, fazendo-a acreditar que o tratamento que eles davam às mulheres era superior ao tratamento dado pelos homens que eles consideravam selvagens. Se as mulheres descobrissem que nem todas as mulheres eram maltratadas, elas poderiam deixar de ser tolerantes para com o abuso dos seus homens ${ }^{76}$.

Portanto, para colonizar um povo cuja sociedade não era hierárquica, os colonizadores deviam primeiro naturalizar a hierarquia através da instituição patriarcal. A violência patriarcal gendrada é o processo pelo qual os colonizadores inserem a hierarquia e a dominação no corpo dos colonizados. Ironicamente, enquanto escravizavam o corpo das mulheres, os colonizadores diziam que estavam, na verdade, libertando de alguma forma as indígenas da "opressão" a que elas supostamente estavam sujeitas nas nações indígenas. Thomas Jefferson argumentou que as mulheres indígenas "estavam submetidas a uma lida injusta. Acredito que esse seja o caso de todas as nações bárbaras. É somente a civilização que coloca a mulher no gozo da sua igualdade" 77 . A Mariposa Gazette, de maneira similar, observou que, quando as mulheres indígenas estavam totalmente sob o controle do homem branco, elas se tornavam “limpas, organizadas e trabalhadoras, e logo aprendiam a cumprir as tarefas domésticas de maneira apropriada e digna"vii. Em 1862, um índio do Conrow Valley foi morto e escalpelado, tendo sua cabeça sido torcida e arrancada. Seus assassinos disseram: "Você não matará mais nenhuma mulher ou criança"78. Aparentemente, as mulheres indígenas só podem ser livres sob o domínio dos homens brancos, e as mulheres brancas e indígenas precisam ser protegidas dos índios, e não do homem branco.

\footnotetext{
vii A Mariposa Gazzete é um jornal do Condado de Mariposa, Califórnia, em circulação semanal desde 1854 [nota da tradução].
}

Espaço Ameríndio, Porto Alegre, v. 8, n. 1, p. 195-230, jan./jun. 2014. 
Um anúncio do cigarro Virginia Slimsviii de 1985 apresentava uma noção similar de como o patriarcado branco salva a mulher indígena da opressão. Do lado esquerdo do anúncio havia um totem com desenhos de índias caricatas. Seus nomes: Princesa Lava e Esfrega, Pequena Colhedora de Água Corrente, Guardiã da Tenda, Princesa que Prepara o Café da Manhã, Almoço e Janta, Índia que Cata Lenha, Princesa Costureira de Pele de Búfalo, Pequena Índia que Passa o Dia Tecendo, e Mulher que Arranca Pena para o Cocar do Cacique. A legenda no topo do totem dizia: "O Virginia Slism lembra de uma das muitas sociedades em que as mulheres estavam à frente dos homens". Do lado direito do anúncio há uma modelo maquiada vestindo uma saia justa, meia-calça de nylon e salto alto, com a conhecida legenda: "Você chegou longe, $b a b y^{\prime \prime}$. A mensagem é que as mulheres indígenas, oprimidas em suas sociedades tribais, precisam ser libertadas para participar de um padrão patriarcal de beleza, onde sua liberdade legítima é alcançada. O registro histórico sugere, como argumenta Paula Gunn Allen, que a raiz verdadeira do feminismo deve ser encontrada nas sociedades indígenas. Porém, nesse anúncio da Virginia Slims, o feminismo está atrelado à conquista colonial - a liberdade das mulheres (brancas) está baseada na destruição das sociedades indígenas supostamente patriarcais.

Hoje, vemos esse discurso sendo utilizado na "guerra contra o terror". Para justificar o bombardeio no Afeganistão, Laura Bush declarou: "a luta contra o terrorismo também é uma luta pelos direitos e pela dignidade da mulher"79. Essa opinião era compartilhada pelas feministas brancas. Elanor Smeal, ex-presidente da NOW - National Organization for women [Organização Nacional das Mulheres] e fundadora e presidente do Fund for a Feminist Majority [Fundo para uma Maioria Feminista] disse: "Sem o 11 de Setembro, não teríamos conseguido chamar tanto à atenção para a tragédia do Afeganistão a ponto das potências mundiais impedirem as atrocidades do talibã ou para tirá-lo do poder. Tragicamente, teve que acontecer um desastre para que tomassem uma atitude definitiva" 80 .

Parece que a melhor maneira de libertar as mulheres é bombardeando-as. Entretanto, a Revolutionary Association of Women of Afghanistan - RAWA [Associação Revolucionária das Mulheres do

viii Virginia Slims é uma marca de cigarros para mulheres, surgida em 1968 [nota da tradução].

Espaço Ameríndio, Porto Alegre, v. 8, n. 1, p. 195-230, jan./jun. 2014. 
Afeganistão], cujos membros eram as próprias mulheres que deveriam ser liberadas por essa guerra, denunciaram a guerra como sendo um empreendimento imperial.

Por diversas vezes, o RAWA avisou que o governo dos Estados Unidos não é um aliado do povo do Afeganistão, primeiro porque, nas duas décadas passadas, ele não poupou esforços ou dinheiro para treinar e armar grupos islâmicos fundamentalistas e um sem número de fanáticos árabes alucinados dos mais sórdidos, traiçoeiros, misóginos e antidemocráticos para lançá-los contra o nosso povo. Após a retirada dos agressores russos e do colapso do regime fantoche de Najib no Afeganistão, essas entidades fundamentalistas se tornaram ainda mais descontroladas. Eles aceitaram oficialmente e sem restrições o jugo de servidão em prol dos interesses de governos estrangeiros, em cuja capacidade eles perpetraram crimes e atrocidades contra o povo do Afeganistão sem precedentes na história de qualquer país do planeta.

O RAWA condena veementemente os ataques aéreos dos Estados Unidos ao Afeganistão, porque a população empobrecida do país - já encurralada em meio à briga entre os talibãs dos Estados Unidos e os lacaios Jihadi - são os que mais sofrem nesses ataques e também porque os Estados Unidos, em sua arrogância de superpotência, desrespeitou a soberania do povo afegão e a integridade territorial afegã.

Os Estados Unidos se dizem contra o terrorismo fundamentalista quando seus próprios interesses são prejudicados; caso contrário, eles se comprazem em ser aliados e patrocinadores de qualquer entidade terrorista-fundamentalista criminosa. Se os Estados Unidos não quer que seu fanatismo ridículo apareça e se realmente quiser eliminar 0 terrorismo fundamentalista, deve aprender com suas próprias políticas míopes ultrapassadas e perceber que a fonte do terrorismo fundamentalista provém do apoio estadunidense aos regimes mais reacionários dos países árabes e não árabes e de sua generosidade militar e financeira aos criminosos fundamentalistas afegãos. O terrorismo somente será extirpado quando essas duas fontes secarem ${ }^{81}$.

Então, por que um grupo como o Fund for a Feminist Majority ignora a voz do RAWA? Novamente, mesmo entre os círculos feministas, prevalece a lógica colonial de que as mulheres de cor, as mulheres 
indígenas e as mulheres do Sul Global são simplesmente as vítimas da opressão, ao invés de serem aquelas que se organizam em seu pleno direito.

A "assimilação" à sociedade branca, entretanto, só aumentou a vulnerabilidade das Indígenas à violência. Por exemplo, quando a nação Cherokee foi deslocada à força para Oklahoma, na Trilha das Lágrimas, no século XIX, os soldados atacavam sexualmente as mulheres cherokee que falavam inglês e haviam frequentado as escolas das missões, ao invés daquelas que não participaram dessas ações assimilacionistas. Com frequência, elas eram estupradas por homens em grupos, fazendo com que um missionário junto aos cherokee, Daniel Butrick, se arrependesse do fato de terem ensinado inglês aos cherokee ${ }^{82}$. Homi Bhabha e Edward Said argumentam que parte do processo de colonização envolve a assimilação parcial do colonizado para que se possa estabelecer o domínio colonial83. Ou seja, se o grupo colonizado parece muito diferente dos colonizadores, ele implicitamente desafia a supremacia do domínio colonial por estar se recusando a se adaptar à maneira de viver dos colonizadores. O colonizado, portanto, deve se parecer parcialmente com os colonizadores para reforçar a ideologia dominante e estabelecer que a maneira como os colonizadores vivem é a única maneira boa de se viver. No entanto, o grupo colonizado nunca pode ser completamente assimilado - senão seriam iguais aos colonizadores, e não haveria razão para colonizá-los. Usando a análise de Bhabha e de Said, pode-se ver que, embora se prometesse às mulheres cherokee que a assimilação thes traria os benefícios da sociedade dominante, na verdade os esforços assimilacionistas as tornavam mais facilmente subjulgadas ao domínio colonial.

Historicamente, os colonizadores brancos que estupravam as índias afirmavam que os verdadeiros estupradores eram os índios ${ }^{84}$. Hoje em dia, os brancos que estupram e matam índias fazem, com frequência, a mesma afirmação. No final dos anos 80 , um branco, Jesse Coulter, estuprou, matou e mutilou diversas índias em Minneapolis. Ele alegava ser índio, tendo adotado o nome de Jesse Sittingcrow e tatuado em seu braço a sigla AIM [American Indian Movement - Movimento Indígena Americano]ix 85.

${ }^{\text {ix }}$ O American Indian Movement foi um movimento ativista pelos direitos civis fundado em 1968,

Espaço Ameríndio, Porto Alegre, v. 8, n. 1, p. 195-230, jan./jun. 2014. 
Roy Martin, um índio não miscigenado, foi acusado de abuso sexual em Bemidji, Minnesota. A sobrevivente identificou o estuprador como branco, 25 anos, de cabelo repicado. Martin tinha 35 anos e seus cabelos passavam dos ombros ${ }^{86}$. Numa pesquisa nos principais jornais sobre a cobertura dada, de 1998 a 2004, aos casos de estupros em comunidades indígenas, encontrei praticamente somente matérias sobre casos onde um indígena (ou um branco se passando por indígena) era o agressor suspeito e a vítima, uma mulher branca; praticamente não havia matérias sobre mulheres indígenas vítimas de abuso sexual. Essa ausência é ainda mais surpreendente quando se considera que as indígenas são mais suscetíveis do que outros grupos de mulheres nos Estados Unidos a serem vítimas de abuso sexual87.

Do mesmo modo, após a Guerra Civil, os homens negros nos Estados Unidos eram sujeitos ao linchamento por seus supostos estupros em massa de mulheres brancas. A crença racista é de que as mulheres brancas precisavam ser protegidas do homem negro predador, quando, na verdade, as mulheres negras precisavam ser protegidas dos homens brancos. Em suas investigações sobre linchamentos ocorridos entre 1865 e 1895, a ativista contra linchamentos, Ida B. Wells, calculou que mais de dez mil pessoas negras haviam sido linchadas. Durante o mesmo período, nenhuma pessoa branca havia sido linchada por estupro ou assassinato de uma pessoa branca ${ }^{88}$. Além disso, embora a razão declarada para tais linchamentos fosse proteger as brancas dos estupradores negros, Wells descobriu que somente um terço dos linchados tinha sequer sido acusado de estupro. Além disso, a maioria dos homens negros acusados de estupro tinham tido relações sexuais claramente consentidas com mulheres brancas ${ }^{89}$.

Sem dúvida, os índios praticam atos de violência sexual. Após anos de colonialismo e da experiência dos internatos, a violência foi internalizada pelas comunidades indígenas. No entanto, essa visão de que o índio é o estuprador "verdadeiro" serve para mascarar quem tem o real poder nessa sociedade racista e patriarcal. Dessa forma, a colonização das mulheres indígenas (assim como de outras mulheres de cor) é parte do projeto de fortalecimento da propriedade do homem

congregando os indígenas deslocados para as cidades e auxiliando para uma retomada de valores tradicionais nas comunidades indígenas [nota da tradução].

Espaço Ameríndio, Porto Alegre, v. 8, n. 1, p. 195-230, jan./jun. 2014. 
branco sobre a mulher branca.

E embora a era dos massacres indígenas, na sua forma mais explícita, tenha chegado ao fim na América no Norte, o estupro e a mutilação indiscriminados dos corpos das indígenas continuam. Durante o massacre do povo maia na Aldea Rio Negro (Guatemala), 177 mulheres e crianças foram mortas. As mulheres jovens foram violentadas na frente das suas mães, e as mães foram mortas na frente dos seus filhos. Depois, as crianças pequenas foram amarradas pelos tornozelos e arremessadas contra as pedras até seus crânios quebrarem. Esse massacre, cometido pelo exército da Guatemala, foi financiado pelo governo dos Estados Unidos 90 .

Num massacre em Chiapas, México, em 1997, mulheres indígenas foram alvo de mutilação sexual, estupro por vários homens e tortura pelas forças paramilitares. A Anistia Internacional relatou que a tortura contra povos indígenas na América Latina é rotineira, incluindo choques elétricos, semiasfixia com sacolas plásticas ou por submersão em água, ameaças de morte, execuções simuladas, espancamento utilizando objetos cortantes, bastões ou rifles, estupros e agressão sexual91.

Podemos nos perguntar por que os estupros em massa na Guatemala, Chiapas, ou de qualquer outra nação indígena na América Latina não causa tanta indignação quanto os estupros na Bósnia nos anos 90. Na verdade, Catherine Mackinnon, uma jurista feminista, argumenta que na Bósnia: "O mundo nunca viu o sexo ser usado de maneira tão consciente, tão cínica, tão elaborada, tão aberta, tão sistemática... como um meio de destruir uma nação por completo [ênfase minha]"92. Aqui, Mackinnon parece ter esquecido que vive nesse país porque milhares de indígenas foram estuprados, mutilados sexualmente e assassinados. Será que o estupro em massa contra mulheres europeias é um genocídio, enquanto o estupro em massa contra mulheres indígenas é uma atividade normal?

O contexto histórico do estupro, do racismo, e do colonialismo continua a atingir as mulheres na América do Norte igualmente. Esse legado é mais evidente nos índices de violência em comunidades indígenas - as indígenas são duas vezes mais suscetíveis de serem vitimas de crimes violentos do que homens ou mulheres de qualquer outro grupo étnico. Além disso, sessenta porcento dos agressores 
contra as indígenas são brancos ${ }^{93}$.

Em épocas de crise, a violência sexual contra as indígenas aumenta vertiginosamente. Quando servi de testemunha pacifista em favor dos caçadores submarinos chippewa, que estavam sendo intimidados por multidões racistas brancas nos anos 80, um agitador branco carregava uma placa que dizia: "Salve um peixe; arpoe uma squaw grávida". Durante a crise mohawkx, em 1990, no Quebec, Canadá, uma multidão de brancos cercou uma ambulância levando uma indígena que precisava sair da reserva mohawk porque estava com hemorragia após ter dado à luz. Ela foi forçada a "abrir as pernas" para provar que tinha acabado de ter um filho. A polícia presente no local se negou a intervir. Um índio foi preso por estar "usando disfarce" (ele estava vestindo calças jeans) e foi brutalmente espancado no local, tendo seus testículos esmagados. Duas mulheres do Women of All Red Nations - WARN [Mulheres de Todas Nações Vermelhas], de Chicago, foram a Oka para filmar a crise. Elas foram presas e mantidas sob custódia por onze horas sem acusação formal, e lhes disseram que não podiam ir ao banheiro a menos que um policial homem as vigiasse. $\mathrm{O}$ local em que foram mantidas estava coberto de revistas pornográficas.

Esse desejo colonial de subjulgar os corpos das índias ficou bastante evidente quando, em 1982, Stuart Kasten comercializou o jogo de videogame "A Vingança de Custer", em que os jogadores ganhavam pontos cada vez que eles, na forma de Custer, estupravam uma índia. O slogan do jogo é "Quando você emplaca nela, você emplaca um ponto". Ele descreve o jogo como "uma série divertida em que a mulher está aproveitando, de bom grado, um ato sexual". De acordo com o material promocional:

Você é o General Custer. Sua raiva está no pico, sua pistola está agitada. Você tem uma linda indiazinha com pés e mãos amarradas e tem a chance de reescrever a história e acertar as contas. Bem, as mãos da índia podem estar atadas, mas ela parece não aceitar, por George! A ajuda está a caminho. Se você for se vingar, precisará estar à altura do desafio, escapar da tribo com flechas velozes e proteger seus flancos contra algum cacto decididamente vil e

\footnotetext{
${ }^{x}$ A Crise Mohawk de 1990, também conhecida como a Crise de Oka, foi uma disputa de terras entre os mohawk e a cidade de Oka, Quebec [nota da tradução].
}

Espaço Ameríndio, Porto Alegre, v. 8, n. 1, p. 195-230, jan./jun. 2014. 
espinhento. Se você puder permanecer composto e sobreviver a cordas e flechas - você pode ser a última defesa. Lembra? A vingança é um prato que se come frio ${ }^{94}$.

Continua a violência sexual como uma ferramenta do racismo também contra outras mulheres de cor. O tráfico de mulheres da Ásia e de outros países do Sul Global segue ininterrupto nos Estados Unidos. De acordo com a CIA, 45 a 50 mil mulheres entram nos Estados Unidos anualmente através do tráfico ${ }^{95}$. Além disso, há cerca de 50 mil noivas sob encomenda das Filipinas somente nos Estados Unidos96. Os homens brancos, interessados em mulheres que eles supõem serem submissas, encomendam noivas por correspondência que, devido ao seu status legal precário, são vulneráveis à violência doméstica e sexual. Como descreve o material promocional para a encomenda de noivas por correspondência, as Filipinas têm "peles excepcionalmente lisas e vaginas firmes... [elas são] esposas de baixo custo de manutenção. Podem sempre ser retornadas e substituídas por um modelo mais jovem"97.

As mulheres de cor também são alvo de violência sexual próximo à fronteira dos Estados Unidos. Os negros e os latinos perfazem $43 \%$ dos investigados em alfândegas, mesmo sendo somente $24 \%$ da população. O American Friends Service Committee [Comitê de Serviços dos Amigos Americanos] ${ }^{x i}$ registrou 346 denúncias de violência gendrada na fronteira entre México e Estados Unidos, de 1993 a 1995 (e esse é o registro de somente uma agência, que não inclui os casos de mulheres que ou não denunciam ou denúnciam em outras agências). Este caso é emblemático do tipo de abuso que a mulher encontra na fronteira: Um fiscal da imigração, Larry Selders, estuprou diversas mulheres durante um longo tempo. Até que, finalmente, uma das vítimas em Nogales, Arizona, teve de processar o governo dos Estados Unidos por não tomar medidas para investigar seu estupro. Selders exigiu sexo da mulher em troca de sua liberação. Quando ela recusou, ele a levou para uma região isolada fora da cidade, estuprou-a e a ameaçou para que não contasse nada para ninguém. Sua defesa

\footnotetext{
xi O American Friends Services Committee é uma organização afiliada à Sociedade Religiosa de Amigos (quakers) para prover ajuda humanitária e trabalhar pela justiça social, pela paz, pela reconciliação, pelos direitos humanos e pela abolição da pena de morte [nota da tradução].
}

Espaço Ameríndio, Porto Alegre, v. 8, n. 1, p. 195-230, jan./jun. 2014. 
descreve em ricos detalhes o trauma horrível que ela continuou a sofrer após o incidente. Mesmo o estupro tendo acontecido em 1993, foi somente em outubro de 1999 que o júri finalmente chegou a uma decisão a favor das vítimas. "O governo encobriu informações sobre atos anteriores cometidos por Selders. Levou mais de três anos de batalhas judiciais para descobrir que, pelo menos, três outras vítimas eram de conhecimento do governo", declarou o advogado da vítima, Jesus Romo ${ }^{98}$.

\section{A Violência Sexual e a Impunidade}

A ideologia de que o corpo das indígenas é violentável fica evidente quando se constata que há centenas de mulheres indígenas desaparecidas no México e no Canadá. Desde 1993, mais de 500 mulheres foram assassinadas em Juarez, México. A maioria delas foi sexualmente mutilada, estuprada e torturada, inclusive tendo seus mamilos extraídos. As mulheres pobres e as indígenas, em particular, têm sido o alvo. Além da polícia local não fazer esforço algum para resolver os casos, parece ser cúmplice nos assassinatos. A Anistia Internacional e outras organizações e ativistas de direitos humanos perceberam a falta de interesse da polícia em investigar mais a fundo os casos - a polícia fez várias prisões e torturou os presos para extrair confissões, mas os assassinatos não diminuíram. Além do mais, a resposta genérica dada pela polícia para os assassinatos é culpar as vítimas justificando que elas são trabalhadoras do sexo ou lésbicas, ou seja, inerentemente estupráveis 99 . Por exemplo, um ex-promotor público comentou em 1999: "É difícil sair na rua quando está chovendo e não se molhar"100.

Do mesmo modo, no Canadá, mais de 500 mulheres das Primeiras Nações desapareceram ou foram assassinadas nos últimos 15 anos, e há muito pouca investigação da polícia. Novamente, parece que seus casos foram negligenciados porque muitas das mulheres era sem-teto ou trabalhadoras do sexo. Ada Elaine Brown, irmã de Terri Brown, presidente da Associação de Mulheres Nativas no Canadá, foi encontrada morta na cama em 2002. Foi de tal modo espancada que sua

Espaço Ameríndio, Porto Alegre, v. 8, n. 1, p. 195-230, jan./jun. 2014. 
família não a reconheceu. De acordo com Terri Brown: "O relatório da autópsia disse que foi aneurisma cerebral. É claro, porque bateram nela até o sumo"101.

Dentro dos Estados Unidos, devido a questões complexas de jurisdição, com frequência os agressores sexuais podem cometer crimes contra indígenas com impunidade. Uma análise da política de justiça criminal estadunidense nos territótrios indígenas ajuda a esclarecer a situação atual. Em Ex Parte Crow Dog (1883), a Suprema Corte reconheceu a autoridade das tribos indígenas sobre a jurisdição criminal em terras indígenas. Em resposta, os Estados Unidos aprovou o Major Crimes Act (1885) [Ato de Crimes Graves], que estabelece que certos "crimes graves" cometidos em territórios indígenas sejam adjudicados pelo sistema de justiça federal. Em 1883, o Bureau of Indian Affairs BIA [Bureau para Assuntos Indígenas]xii criou a Court of Indian Offenses [Corte de Delitos Indígenas], que indicou oficiais das tribos para estabelecer punições baseadas no padrão anglo-americano de leis. Essas cortes eram responsáveis pela aplicação do Code of Federal Regulations - CFR [Código de Regulamentações Federais], uma compilação de regulamentações emitida pelas agências federais administrativas, que geralmente enfatizava as leis direcionadas à assimilação dos povos indígenas, tais como as leis que proíbem a prática de religiões indígenas.

Os anos 50 introduziu o que chamamos de "período do término" na política indígena dos Estados Unidos. O governo iniciou uma política para acabar com o status tribal de muitas tribos indígenas e implantou programas de realocação para encorajar os indígenas a se deslocarem para áreas urbanas e para assimilá-los à sociedade dominante. Durante esse período, o governo dos Estados Unidos bruscamente retirou o apoio financeiro do sistema jurídico dos territórios indígenas, deixando muitas tribos - que não tinham seu sistema tradicional intacto - sem apoio jurídico algum.

Depois de eliminar os sistemas jurídicos das tribos, o governo dos Estados Unidos aprovou a Public Law 280 (PL 280) [Lei pública 280], em 1953, concedendo aos estados da federação jurisdição criminal e civil

\footnotetext{
xii O BIA é o órgão estadunidense que desempenha funções equivalentes à FUNAI brasileira [nota da tradução].
}

Espaço Ameríndio, Porto Alegre, v. 8, n. 1, p. 195-230, jan./jun. 2014. 
limitada para tribos amparadas pelo Major Crimes Act, sem o consenso das tribos. A PL 280 é a maior infração à soberania indígena, já que as tribos normalmente não são amparadas pela justiça dos estados. Ou seja, embora a política de governo dos Estados Unidos considere as tribos como estando sob a guarda do governo federal, as tribos devem ser reconhecidas como soberanas até certo ponto e não sob a jurisdição do governo dos estados.

Em 1968, os Estados Unidos tomaram medidas para que as tribos desistissem da PL 280 - no entanto, o recuo só poderia ser aceito com a permissão dos estados. Entretanto, decisões judiciais posteriores observaram que a PL 280 permite a jurisdição simultânea de estados ao invés de prover uma jurisdição que se imponha de modo absoluto sobre a jurisdição tribal. Isto é, embora os estados tenham o direito de julgar casos em tribos sob a PL 280 , essas tribos podem julgar os casos, ao mesmo tempo, em suas cortes tribais, se as tiverem.

Entretanto, com o advento do que é conhecido como o período da "auto-determinação" na política indígena dos Estados Unidos, com início em 1968, muitas tribos - em particular as tribos não amparadas pela PL 280 - começaram a desenvolver seus próprios governos tribais. E como resultado, hoje em dia, mais de 140 tribos têm o seu próprio sistema judicial. Dessas, cerca de 25 mantiveram os sistemas CFR com juízes indicados pelo BIA, e outras têm seus próprios tribunais tribais. Algumas tribos, que operam sob o olhar vigilante do governo dos Estados Unidos, nunca perderam seus modelos tradicionais e continuam a praticá-los ainda hoje.

Mas, considerando-se que o estupro enquadra-se no Major Crimes $A c t$, as tribos, em geral, são dependentes do governo federal para processar casos de agressão sexual. Os representantes do Departamento de Justiça dos Estados Unidos informalmente declararam que os advogados dos Estados Unidos se negam a processar cerca de $75 \%$ de todos os casos que envolvem qualquer crime em território indígena. Os advogados dos Estados Unidos são particularmente relutantes para processar casos de estupro; de fato, em 1997 o Departamento de Justiça relatou que somente dois advogados processam regularmente casos de estupro nos territórios indígenas 102 .

Já que as agressões sexuais estão enquadradas no Major Crimes

Espaço Ameríndio, Porto Alegre, v. 8, n. 1, p. 195-230, jan./jun. 2014. 
$A c t$, muitas tribos não desenvolveram códigos para lidar com aqueles casos de estupro que o governo se nega a processar. Aquelas que têm códigos, com frequência, têm o seu poder de investigação comprometido pela espera, que pode durar mais de um ano, até que investigadores federais formalmente repassem os casos. Além disso, o Indian Civil Rights Act - ICRA [Ato dos Direitos Civis Indígenas], de 1968, limita a punição que os sistemas de justiça tribais podem aplicar aos agressores ${ }^{103}$. Por exemplo, o tempo máximo de prisão a que alguém pode ser sentenciado pelos tribunais tribais é de um ano'104. Do mesmo modo, a ativista indígena Sarah Deer (muscogee) observa que os Estados Unidos podem proibir soluções que não sigam as mesmas punições do sistema dominante. Por isso, sentenciar alguém com banimento ou com outra forma tradicional de punição pode ser considerada uma violação ao ICRA ${ }^{105}$. Além disso, os tribunais dos Estados Unidos tomam decisões de maneira conflitante sobre se o Major Crime Acts de fato permite que as tribos mantenham uma jurisdição simultânea em certos crimes, incluindo a agressão sexual ${ }^{106}$.

Para complicar ainda mais as coisas, as tribos sob a PL 280 - que dá jurisdição criminal aos Estados - devem lidar com funcionários públicos dos estados e municípios que talvez tenham relações hostis com as tribos. E por causa da frequente localização geográfica isolada - as reservas, às vezes, ficam a mais de $160 \mathrm{~km}$ de distância das autoridades legais mais próximas, e muitas casas não tem telefone - os funcionários não conseguem atender a uma situação de emergência. $O$ racismo por parte da policia de cidades vizinhas à fronteira também contribui para a falta de atendimento em casos de estupro. E já que o governo federal não compensa os governos dos estados pela aplicação da lei nas reservas, e as tribos normalmente não pagam tributos locais ou federais, os estados têm pouco interesse em dar "proteção" às tribos indígenas.

Por fim, as tribos indígenas não tem o direito de processar pessoas não indígenas pelos crimes que ocorrem nas reservas. No caso Oliphant v. Suquamish Indian Tribe (1978), a Suprema Corte declarou que as tribos indígenas estadunidenses não possuem jurisdição criminal sobre pessoas não indígenas nas reservas. Esse precedente é particularmente problemático para tribos não amparadas pela PL 280, 
porque a polícia tribal não pode prender pessoas não indígenas que cometam delitos. Ademais, os estados não possuem jurisdição para aplicação da legislação nas reservas. Então, a menos que a aplicação da lei nos estados seja completamente adequada à aplicação da legislação tribal, ninguém poderá condenar agressores não indígenas por crimes em terras indígenas 107.

Em resposta a essas condições deploráveis, muitos povos indígenas estão solicitando maiores financiamentos para a aplicação de justiça criminal em comunidades tribais. É inegável que a política dos Estados Unidos codificou a "estuprabilidade" das mulheres indígenas. De fato, os Estados Unidos e outros países colonizadores estão envolvidos numa "guerra social permanente" contra os corpos das mulheres de cor e das mulheres indígenas, que ameaçam sua legitimidade108. Os colonizadores evidentemente reconhecem a sabedoria do provérbio cheyenne que diz: "Uma nação não está conquistada até que o coração das mulheres esteja derrubado".

\section{REFERÊNCIAS}

Susan Brownmiller, Against Our Will (Toronto: Bantam Books, 1968).

2 Kimberle Crenshaw, "The Intersection of Race and Gender," in Critical Race Theory, ed. Kimberle Crenshaw, et al. (New York: New Press, 1996).

3 Neferti Tadiar, "Sexual Economies of the Asia-Pacific," in What's in a Rim? Critical Perspectives on the Pacific Region Idea, ed. Arif Dirlik (Boulder: Westview Press, 1993).

4 Ibid.

5 Ann Stoler, Race and the Education of Desire (Chapel Hill: Duke University Press, 1997).

6 Ibid.

7 Ella Shohat and Robert Stam, Unthinking Eurocentrism (London: Routledge, 1994).

8 James Rawls, Indians of California: The Changing Image (Norman: University of Oklahoma, 1997).

9 Ibid.

10 Andre Lopez, Pagans in Our Midst (Mohawk Nation: Awkesasne Notes, n.d.).

11 Albert Cave, "Canaanites in a Promised Land," American Indian Quarterly, (Fall, 1988); H. C. Porter, The Inconstant Savage. (London: Gerald Duckworth \& Co., 1979); Robert Warrior, "Canaanites, Cowboys, and Indians," in Voices from the Margin, ed. R. S. Sugirtharajah (Maryknoll: Orbis, 1991). 
12 Robert Berkhofer, The White Man's Indian (New York: Vintage, 1978).

13 David Stannard, American Holocaust (Oxford: Oxford University Press, 1992).

14 David Wrone and Russell Nelson, eds., Who's the Savage? (Malabar: Robert Krieger Publishing, 1982).

15 Ibid.

16 Ibid.

17 Ibid.

18 Ibid.

19 Stannard, American Holocaust.

${ }^{20}$ Wrone and Nelson, Who's the Savage?

21 Press Conference, Chicago, Illinois, August 17, 1990.

22 Andrea Hermann and Maureen O'Donnell, "Indians Rap Thompson over Burial Site Display," Chicago Sun Times, August 17, 1990. Como resultado dos esforços da organização dos indígenas de Illinois, o local foi finalmente fechado, mas os restos mortais não foram novamente enterrados quando o governo seguinte foi empossado.

${ }^{23}$ Terry Pedwell, "Flaherty Slammed by Opposition over Native Health-Care Comments" (Canadian Press, January 21, 2002; available from http://www.bluecorncomics.com/stype215.htm.)

24 Aime Cesaire, Discourse on Colonialism (New York: Monthly Review Press, 1972).

25 Stoler, Race and the Education of Desire.

${ }^{26}$ Ellen Bass and Laura Davis, Courage to Heal (New York: Harper \& Row, 1988).

27 Celia Haig-Brown, Resistance and Renewal (Vancouver: Tilacrum, 1988).

${ }^{28}$ Chrystos, Fugitive Colors (Vancouver: Press Gang, 1995).

${ }^{29}$ Frantz Fanon, Wretched of the Earth (New York: Grove Press, 1963).

30 Michael Taussig, Shamanism, Colonialism and the Wild Man. Chicago: University of Chicago Press, 1991).

31 Native American Women's Health Education Resource Center, "Discrimination and the Double Whammy." (Lake Andes, South Dakota: 1990).

32 Sonia Shah, "Judge Rules Rape of Aboriginal Girl 'Traditional"” (Women's E-News, November 29, 2002; available from http://www.feminist.com/news/news126.html.)

33 Ibid.

34 Taussig, Shamanism, Colonialism and the Wild Man.

35 Fanon, Wretched of the Earth.

36 Tadiar, "Sexual Economies of the Asia-Pacific."

37 Stoler, Race and the Education of Desire

38 Kirpatrick Sale, The Conquest of Paradise (New York: Plume, 1990).

39 Wrone and Nelson, Who's the Savage?

40 Bartolome de Las Casas, Devastation of the Indies, trans. Herma Briffault (Baltimore: John Hopkins University Press, 1992).

${ }^{41}$ Sand Creek Massacre: A Documentary History (New York: Sol Lewis, 1973).

43 Angela Davis, Women, Race and Class (New York: Vintage, 1981).

44 Eugene Genovese, Roll, Jordan, Roll (New York: Vintage, 1976).

45 Clifton Johnson, ed., God Struck Me Dead. (Cleveland: Pilgrim Press, 1969).

${ }^{46}$ Herbert Gutman, Black Family in Slavery and Freedom. (New York: Vintage, 1976).

47 Thomas Almaguer, Racial Faultlines. (Berkeley: University of California, 1994).

48 Karen Warren, "A Feminist Philosophical Perspective on Ecofeminist Spiritualities," in Ecofeminism and the Sacred, ed. Carol Adams (New York: Continuum, 1993).

49 Stannard, American Holocaust.

Espaço Ameríndio, Porto Alegre, v. 8, n. 1, p. 195-230, jan./jun. 2014. 
50 Mary Daly, Gyn/Ecology (Boston: Beacon Press, 1978); Andrea Dworkin, Woman Hating (New York: E. P. Dutton, 1974); Anne Barstow, Witchcraze (New York: Dover, 1994); Barbara Ehrenreich, and Deirdre English, For Her Own Good (Garden City: Anchor, 1979); Rosemary Radford Ruether, ed., Religion and Sexism (New York: Simon \& Schuster, 1974); Rosemary Radford Ruether, New Woman, New Earth (Minneapolis: Seabury Press, 1975); Stannard, American Holocaust.

51 Matilda Joslyn Gage, Women, Church and State (Watertown, MA: Persephone Press, 1980).

52 Stannard, American Holocaust.

53 Ehrenreich and English, For Her Own Good.

54 Stannard, American Holocaust.

55 Wrone and Nelson, Who's the Savage?

56 Barry O'Connell, ed., On Our Own Ground: The Complete Writings of William Apess, a Pequot. (Amherst: University of Massachusetts, 1992).

57 Shohat and Stam. Unthinking Eurocentrism.

58 M. Annette Jaimes and Theresa Halsey, "American Indian Women: At the Center of Indigenous Resistance in North America," in State of Native America, ed. M. Annette Jaimes (Boston: South End Press, 1992).

59 Paula Gunn Allen, The Sacred Hoop. (Boston: Beacon, 1986).

60 Jaimes and Halsey, "American Indian Women."

61 Tom Holm, "Patriots and Pawns," in State of Native American, ed. M. Annette Jaimes (Boston: South End Press, 1992).

62 Jane Richardson, Law and Status among the Kiowa Indians. (New York: JJ Augustin, 1940).

63 “Anishinabe Values/Social Law Regarding Wife Battery," Indigenous Woman 1, no. 3, (n.d.). Para pontos de vista semelhantes, veja Charon Asetoyer, "Health and Reproductive Rights," in Indigenous Women Address the World, ed. Indigenous Women's Network (Austin: Indigenous Women's Network 1995); Division of Indian Work Sexual Assault Project, "Sexual Assault Is Not an Indian Tradition," (Minneapolis, n.d.).

${ }^{64}$ Mary Rowlandson, A Narrative of the Captivity and Removes of Mrs. Mary Rowlandson (Fairfield: Ye Talleon Press, 1974).

65 June Namias, White Captives (Chapel Hill: University of North Carolina Press, 1993). Não estou afirmando que a natureza não patriarcal das sociedades indígenas é a única razão que levou as mulheres brancas a escolherem viver com seus raptores, mas essa é uma explicação possível do porquê tantas escolherem ficar.

${ }^{66}$ Lopez, Pagans in Our Midst.

${ }^{67}$ Ibid.

68 É difícil determinar a real natureza da captura de brancos por índios com base nestas narrativas devido a sua visão anti-índios. Por exemplo, A Narrative of the Horrid Massacre by the Indians of the Wife and Children of the Christian Hermit faz tudo para provar que os índios são tão cruéis na sua natureza biológica que não há nada mais que os brancos possam fazer a não ser exterminá-los. No entanto, até mesmo o narrador admite que os índios mataram sua família porque ele "destruiu sua aldeia". Mais adiante, ele afima que os índios "são gentis e acolhedores, mas contra aqueles que intencionalmente [grifo meu] os ofendem, o salvagem ocidental [sic] é implacável". A Narrative of the Horrid Massacre by the Indians of the Wife and Children of the Christian Hermit (Saint Louis: Leander W. Whiteney and Co., 1833).

Espaço Ameríndio, Porto Alegre, v. 8, n. 1, p. 195-230, jan./jun. 2014. 
June Namias sugere que a captura de pessoas brancas se tornou mais brutal a medida que o conquistador levou as nações indígenas ao desespero. Ela também diz que, considerando que a narrativa de cativeiro dos Jesuítas parece ser a de natureza mais gráfica, é possível que tenham embelezado suas histórias para realçar suas condições de mártires e aumentar o financiamento de suas missões. Namias, White Captives. Francis Jennings também comenta que havia prática de tortura entre os iroquois, embora não houvesse em outras tribos do nordeste, e que ela se tornou mais acentuada à medida que a conquista dessa nação se tornou mais brutal. Contudo, afirma que os indígenas nunca molestavam mulheres ou meninas. Francis Jennings, Invasion of the Americas (New York: Norton, 1975). Richard Drinnon acredita que a maior parte dos homens capturados fossem assassinados, com exceção daqueles que pudessem ser adotados pela tribo para substituir aqueles que morreram em batalhas. As mulheres e as crianças não eram assassinadas. Richard Drinnon, Facing West (New York: Schocken Books, 1980). Todas essas discussões estão baseadas nas práticas indígenas de depois da colonização e da infusão de violência nessas sociedades.

69 James Seaver, Narrative of the Life of Mrs. Mary Jemison (New York: Corinth Books, 1975).

${ }^{70}$ Ibid.

71 Carol Adams, Neither Man nor Beast (New York; Continuum, 1994).

72 Andrea Dworkin, Pornography (New York: Periree, 1981).

73 Namias, White Captives.

74 Jane Caputi, Age of Sex Crime. (Bowling Green, OH: Popular Press, 1987).

75 Allen, The Sacred Hoop.

76 Paula Gunn Allen, "Violence and the American Indian Woman," in The Speaking Profits Us, ed., Maryviolet Burns (Seattle: Center for the Prevention of Sexual and Domestic Violence, 1986).

77 Roy Harvey Pearce, Savagism and Civilization (Baltimore: John Hopkins Press, 1965).

78 Rawls, Indians of California.

${ }^{79}$ Laura Flanders, "What has George W. Ever Done for Women?" The Guardian, March 26, 2004.

${ }^{80}$ Ellie Smeal, Fund For a Feminist Majority, 2001.

81 RAWA, "The U.S. Bares Its Fangs to Its Flunkeys," http://rawa.fancymarketing.net/attacke.htm, August 21, 1998.

82 E. Raymond Evans, "Fort Marr Blockhouse," Journal of Cherokee Studies 2, no. 2 (1977).

${ }^{83}$ Homi Bhabha, "Of Mimicry and Men," in Tensions of Empire, ed. Frederick Cooper and Ann Laura Stoler (Berkeley: University of California Press, 1997); Edward Said, Orientalism (New York: Vintage, 1994).

${ }^{84}$ Wrone and Nelson, Who's the Savage?

${ }^{85}$ Mark Brunswick and Paul Klauda, "Possible Suspect in Serial Killings Jailed in New Mexico," Minneapolis Star and Tribune, May 28, 1987.

86 "Indian Being Tried for Rape with No Evidence," Fargo Forum January 9, 1995.

${ }^{87}$ Lawrence Greenfield and Steven Smith, "American Indians and Crime," (Washington, D.C.: Bureau of Justice Statistics: U.S. Department of Justice, 1999).

88 Davis, Women, Race and Class.

89 Paula Giddings, Where and When I Enter. (New York: Bantam Books, 1984). 
90 Dona Antonia, lecture, University of California-Davis, 1996.

91 Amnesty International, "Mexico: Under the shadow of Impunity," March 9, 1999, http://web.amnesty.org/library/index/engAMR410021999?open\&of=eng-2am

92 Catherine Mackinnon, "Postmodern Genocide," Ms., July/August, 1993.

93 Greenfield and Smith, American Indians and Crime. Os jovens indígenas tem quarenta e nove porcento a mais de chances de serem vítimas de crimes violentos do que o próximo grupo étnico mais suscetível - os afro-americanos. National Center for Victims of Crime, http://www.ncvc.org.

94 Promotional material from Public Relations: Mahoney/Wasserman \& Associates, Los Angeles, CA, n.d.

95 Joe Brinkley, "CIA Reports Widespread Immigrant Sexual Slavery," San Francisco Examiner, April 2, 2000.

96 Neferti Tadiar, "Colonization and Violence Against Women of Color," lecture, The Color of Violence: Violence Against Women of Color Conference, University of California-Santa Cruz, April, 2000.

97 Ibid.

98 Anannya Bhattacharjee, In Whose Safety? Women of Color and the Violence of Law Enforcement (Philadelphia: American Friends Service Committee, 2001).

99 Bill Hewitt, "A Wave of Murders Terrorizes the Women of Ciudad Juarez," People, August 25, 2003; Evelyn Nieves, "To Work and Die in Juarez," Mother Jones. May/June, 2002.

${ }^{100}$ Amnesty International, Mexico, "Intolerable Killings: Ten years of abductions and murders in Ciudad Juarez and Chihuahua," August 11, 2003.

101 Linda Diebel, "500 Missing: Aboriginal Canadians Take Fight for Justice for Invisible Victims to U.N.," Toronto Star, November 30, 2002.

102 Essa informação foi fornecida pelos representantes do Departamento de Justiça no Strategic Planning Meeting on Crime and Justice Research in Indian Country (Portland, Oregon), October 14-15,1998 e a Mending the Sacred Hoop Faculty Development Session (Memphis, Tennessee) May 21-23, 1998.

${ }^{103}$ O Indian Civil Rights Act foi ostensivamente aprovado para proteger os direitos civis nas nações indígenas, mas o efeito dessa lei era restringir a soberania tribal sobre seus membros, se as ações tribais infringissem os "direitos civis" dos seus membros, conforme compreensão do governo dos Estados Unidos. Consequentemente, nos casos de violência sexual, os tipos de estratégias e punições que as tribos podem utilizar estão limitados aos tipos de estratégias e punições que são tidos como aceitáveis pelo governo dos Estados Unidos.

${ }^{104}$ Para uma história da política indígena, veja Sharon O’Brien: American Indian Tribal Governments (Norman: University of Oklahoma, 1989); Luana Ross, Inventing the Savage: The Social Construction of Native American Criminality (Austin: University of Texas Press, 1998); Carole Goldberg, Planting Tail Feathers (Los Angeles: American Indian Studies Center, UCLA, 1997). Para mais referências sobre a política atual de justiça criminal, consulte o website da Tribal Law and Policy Institute [Instituto de Direito e Políticas Tribais], Los Angeles, CA <www.tribalinstitute.org.>

105 Sarah Deer, "Expanding the Network of Safety: Tribal Protection Orders and Victims of Sexual Assault," artigo não publicado.

${ }^{106}$ Ibid.

${ }^{107}$ Ibid.

Espaço Ameríndio, Porto Alegre, v. 8, n. 1, p. 195-230, jan./jun. 2014. 
ANDREA SMITH - A violência sexual como uma ferramenta de genocídio

${ }^{108}$ Stoler, Race and the Education of Desire.

Espaço Ameríndio, Porto Alegre, v. 8, n. 1, p. 195-230, jan./jun. 2014. 